\title{
The Application of Flipping Classroom Teaching Model in Computer Teaching in Higher Vocational Education
}

\author{
Li Wang \\ Institute of Technology \\ East China Jiaotong University, \\ JiangXi, China
}

\author{
Yi-Dan Xu \\ Institute of Technology \\ East China Jiaotong University, \\ JiangXi, China
}

\begin{abstract}
With the continuous development of our society, the education of our country has also been greatly developed. More and more good methods are used in the daily teaching activities. The flipped classroom te aching mode (FCTM) is a new teaching mode, which is widely used in the teaching activities of various subjects. This paper focuses on the deficiency of computer teaching in higher vocational education in our country, the role of FCTM in computer teaching process, and the application of FCTM in computer teaching process in higher vocational education. This paper analyzes the application of FCTM in higher vocational computer teaching.
\end{abstract}

Keywords-flipped-classroom; higher vocational education; application

\section{INTRODUCTION}

With the continuous development of computer technology in our country, higher vocational schools in our country have generally carried out computer teaching courses, In the traditional computer teaching process, the computer teaching model and the teaching contents have not been innovated for a long time, and they have been unable to follow the development of the times[1]. In this case, what the students are learning in the classroom has become out of step with the times. Students can't learn more advanced cultural knowledge in the classroom, their own comprehensive ability can't be improved, so that students can't quickly adapt to work and learning when they go to work. As a new type of teaching mode, flipped classroom teaching mode (FCTM) can effectively solve the problem of insufficient innovation in the process of computer teaching in higher vocational education [2]. It also plays a vital role in activating classroom atmosphere and inspiring students' learning enthusiasm.

\section{THE DEFICIENCY OF COMPUTER TEACHING IN HIGHER VOCATIONAL EDUCATION}

In the traditional computer teaching process of higher vocational education in China, there are still many shortcomings in computer teaching methods and teaching concepts in higher vocational education. For example, in the process of computer teaching in higher vocational education, the teaching mode and teaching method are old, the computer course system is not perfect in the course of computer teaching in higher vocational education, and the examination mechanism is not comprehensive in the process of computer teaching in higher vocational education. The following is mainly from these aspects of the specific analysis.

\section{A. The teaching mode and teaching method are outdated}

With the continuous development of Internet technology in China, internet technology has been widely used in our people's life and learning process, and got very good achievements. Great changes have taken place in the way our people live and study. Nowadays, most families in our country have their own computers and students will use computers for study and entertainment in their spare time. Most students can easily master some basic knowledge about computers. At the same time, many students are also very good at the actual operation of the computer [3]. However, in the course of practical computer teaching in higher vocational colleges, many teachers do not take these problems into consideration. They only explain the teaching contents to students according to the traditional teaching methods and teaching contents, and according to the teaching textbooks which teaching method is too old. It can't keep up with the pace of the development of the times, not only can not improve the computer skills of students effectively, but also make students lose enthusiasm for learning[4].

\section{B. Computer curriculum system is not perfect}

Computer technology has been widely used in various industries, in the normal process of work, there is a lot of work is dependent on computer technology, Therefore, it requires that students must master the basic computer operation, so that students in the future work will not be unable to use the computer and delay work. However, computers are a subject that involves a wide range of knowledge points, and computer technology used in different industries is only a small part of computer technology. Therefore, in the process of arranging computer courses for students, students from different specialties should have a full consideration to their major. Students from different majors should arrange different basic computer courses so as to truly combine computer courses with specialized courses learned by students. Let the computer basic courses play the role of auxiliary professional courses, so that students in the future work process, can adapt to the working environment faster, faster to adapt to the basic requirements of 
computer skills in different positions.

\section{The examination mechanism is not comprehensive}

In the traditional higher vocational computer teaching process, teachers only blindly teach knowledge to the student while the student only carries on the understanding and the memory which the teacher teaches. Since the teaching contents arranged by teachers are all content of teaching assessment. The students are also active in learning what the teacher teaches in order to prepare for the exam. In the process of computer teaching in higher vocational colleges, teachers will not explain knowledge other than examination for students. Even if it is the expanded knowledge in textbooks, teachers will not explain to students, but only arrange for students to learn by themselves. Some students think that the content is not the content of the examination, so they will not study in such a teaching mode, the content of students' learning is very limited. They only study the contents of the examination. Both the students and the teachers ignore the real significance of learning, only to arrange for examinations. Not only the students' computer ability can't be improved, but also the students' autonomous learning ability, as well as the students' own comprehensive quality can't be improved.

\section{THE ROLE OF FCTM}

\section{A. It can effectively highlight the main position of the students}

FCTM can effectively highlight the main position of students. Under the FCTM, teachers pay more attention to the development process of students' individuation and the cultivation of students' individualized thinking ability. In this teaching mode, students can not only improve their own computer level, but also can effectively improve their own innovative thinking ability, as well as their own independent learning ability and students' comprehensive quality will be greatly improved.

\section{B. It can provide individualized learning environment for students}

In the traditional higher vocational computer teaching process, the teacher only prepares the teaching content for the student according to the teaching outline. In the classroom, the teacher teaches the prepared teaching content to the student. But in this kind of teaching process, some students with poor learning ability do not really master the teaching content. With the continuous progress of the teaching process, they do not master more and more teaching content, which will make them lose their interest in learning, and even produce the mood of weariness. The FCTM can effectively solve the problem of insufficient teaching time and teaching space. According to their actual situation, students can use their spare time to study through the Internet, which can effectively solve the problem of different learning progress of different students. Teachers can also organize students to conduct after-class discussions on the Internet so that students can have a deeper understanding of the learning content from the discussion. The positive communication between teachers and students and the positive communication between students and students can also effectively improve the students' language expression ability and help students to improve their comprehensive quality.

\section{It can improve computer classroom management model}

In the process of computer teaching in higher vocational education, teachers use the FCTM. In fact, they record their own teaching process into video and upload it to the Internet platform. These teaching videos will be permanently preserved on the Internet platform. Students can use their spare time to watch and learn on Internet platforms. The FCTM not only provides a new teaching model for teachers, but also provides a new learning model for students. This new learning model can effectively stimulate students' enthusiasm for learning. At the same time, teachers can make full use of classroom time, explain some teaching difficulties and key points for students, and solve the problems they encounter in watching the teaching video. Teachers can also use classroom time to discuss with students to help students understand the content more fully. In the process, not only students' computer skills can be improved effectively, the relationship between teachers and students can also be more harmonious.

\section{THE APPLICATION OF FCTM IN THE PROCESS OF} COMPUTER TEACHING IN HIGHER VOCATIONAL EDUCATION

\section{A. Application in the process of introducing knowledge points before class}

Before the formal beginning of computer teaching content in higher vocational colleges, teachers should prepare students for the introduction of teaching content. Vivid and interesting teaching contents can effectively stimulate students' interest in learning and help students enter the classroom teaching process more quickly. Therefore, in the process of introducing computer before the introduction of higher vocational schools, teachers can use the FCTM for students to record the introduction of teaching video before class. In the video, the teacher can list the teaching objectives and the teaching tasks for the students in detail. The students can watch the video one day before the teacher does the teaching, and then teach themselves, and in the next day of teaching, the students can watch the video. Students can listen with questions in mind, so that students will pay more attention to the teacher's explanation. Especially when the students do not understand, the students will listen more carefully. If the students have not understood in the classroom, they can discuss with their classmates during the class discussion or with the teacher to solve this problem actively. This teaching model can effectively cultivate students' autonomous learning ability, and help students to improve their own thinking ability and problem-solving ability.

\section{B. Application in the course of internalization of classroom knowledge}

Different students have their own good parts. Some students are good at calculation, some students are good at understanding, and some students are good at memory. Teachers should attach great importance to the differences between different students in the teaching process of higher vocational computer. After the students have watched the video, the teacher should fully understand the situation of each student; collect the problems encountered by the students in the course of watching, and then sum up these problems. Then teachers divide the students into different study groups, and let 
the students discuss the issues themselves. After the discussion, each group can send a representative to share the results of their group discussions with you. Finally, the teacher will discuss the results of the summary and supplement. Such a teaching model can create a positive learning atmosphere for students, fully stimulate students' enthusiasm for learning, and make the FCTM play its real role.

\section{SuMmary}

To sum up, in the process of computer teaching in higher vocational education, teachers should follow the principle of gradual and orderly, and constantly find out the problems in teaching in the process of teaching, and carry on positive thinking and solve the problems in time. In the process of computer teaching in higher vocational education, teachers can effectively improve the teaching quality and efficiency by using the FCTM, but the standardization and systematization of the FCTM is not perfect enough. The educators still need to make efforts to improve the FCTM and use the FCTM scientifically and reasonably in the process of computer teaching in higher vocational education, and give play to the real role of the FCTM.

\section{REFERENCES}

[1] Zhao Tao .Application of Flipped Classroom Teaching Model in Computer Teaching in Higher Vocational Education [J] .Contemporary Educational Practice and Teaching Research (Electronic Journal, 2017, pp. 728).(In Chinese)

[2] Liu Lina. Research on the Application of Flipped classroom Teaching Model Based on Micro-course in Computer basic Teaching [J] .Reading Abstract No. 2016, pp. 223-223. (In Chinese)

[3] Lin Q S. Design of Experiment Course "Modern Educational Technology” Based on Flipped Classroom. Research \& Exploration in Laboratory, 2014.

[4] Y Huang, L Jiang, L Huang. The Application Research on Flipped Classroom Model in Experimental Course of "Modern Educational Technology". China Educational Technology,2014 